\title{
A Study of Occupational Stress and Job Satisfaction of Police Personnel of Gujarat State
}

\author{
Parmar Vishal Kumar P. ${ }^{1 *}$, Aastha Dhingra ${ }^{2}$
}

\section{ABSTRACT}

The present research was conducted in order to understand the occupational stress faced by the police personnel of Gujarat state and their levels of Job satisfaction with their lives. A total sample of 120 (60 males and 60 females) were taken for the study. Out of the 120 sample, 60 were armed and 60 were Unarmed Police Offices. Occupational Stress scale developed by A.K Shrivastava and A. P. Singh and Job Satisfaction scale developed by Singh and Sharma were used to gather data. The analysis of data was completed using t-test. The results of this study indicate that there is no significant difference in Occupational stress of Armed and Unarmed Police officers and similarly there is no significant difference in Occupational stress of Male and Female Police officers of both the groups. Moreover there is no significant difference in job satisfaction level of Armed and Unarmed Police officers. There is a significant difference in Job satisfaction level of Male and Female Police officers which indicates that Female police officers have higher levels of Job satisfaction than Male Police officers.

Keywords: Occupational Stress, Job Satisfaction, Police officers, Armed, Unarmed, Male, Female

Many workers face occupational stress as a part of their routine life and have started being a major hazard. By definition, it could be stated as any stress which is related to an individual's work area. When work becomes demanding and a person cannot find enough resources to cope with it, occupational stress comes into picture. Many of the causes of stressful working conditions include increased workloads, downsizing, overtime, hostile work environments, and shift work among others. Factors like ability of the employee and how he/she copes in times of stress, role of the concerned organization and its expectations from the employees, interpersonal relationships at workplace and organizational climate and its suitability for productive work to take place also play a vital role in helping to manage occupational stress.

\footnotetext{
${ }^{1}$ M.Phil In Forensic Psychology, Institute Of Behvavioural Science, Gujarat Fornesic Sciences University, Gandhinagar, Gujarat

${ }^{2}$ M.Phil Clinical Psychology, $\mathrm{II}^{\text {nd }}$ Year Trainee, Amity University, Jaipur

*Responding Author

(C) 2016 I V Parmar, A Dhingra; licensee IJIP. This is an Open Access Research distributed under the terms of the Creative Commons Attribution License (http://creativecommons.org/licenses/by/2.0), which permits unrestricted use, distribution, and reproduction in any Medium, provided the original work is properly cited.
} 
In simple words, life satisfaction can be defined as to how an individual looks upon his/her life, how he/she evaluates it and what he/she thinks about it. It is basically the feeling regarding how one perceives his/her life. Well-being of a person could be assessed by evaluating his mood, satisfaction with his relationships and goals achieved in life. How a person assesses his own self in terms of managing daily life is also important. Life satisfaction has been measured in relation to the experiences an individual has in life, economic conditions, current feelings and attitude.

Police personnel are no super humans and thus, stress in their lives is not an uncommon thought to think about. Regular exposure to human indecency, pain, suspicious environment, danger, job shifts and others can lead to a huge amount of stress. This increasing amount of stress later leads to issues related to physical and mental health which gets reflected in the form of high suicide rates, divorce, alcoholism and decreased job satisfaction and others. Researches have revealed that the job of police personnel are very stressful and impairs health and results in high rates of mental illness also. Usually the organization and management have been the reason of creating dissatisfaction, suppression, suspension, delayed promotions, non-granting of leaves when needed and other department work. A few specific stressors are common among the Indian police personnel which include work overload, lack of recognition, fear of severe injury or being killed on duty, work conditions, shooting, frequent confrontations and many more.

The nature of the Constitution of India mandates law and order as a subject of the state, and therefore the major bulk of the policing lies with the respective states and territories of the country. Law enforcement in India is performed by numerous law enforcement agencies. All central agencies are controlled by the central Government of India. The majority of federal law enforcement agencies are controlled by the Ministry of Home Affairs. The Indian Border Security Force is responsible for guarding India's land borders during peacetime and preventing trans-border crimes operating under the Union Ministry of Home Affairs whereas the Central Industrial Security Force provides industrial security which guards industrial installations around the country owned by the Central Government as well as securing seaports and airports. The Central Reserve Police Force assists and helps state and union territories law enforcement agencies in maintaining law and order and to contain insurgency. The Central Bureau of Investigation is one of the prime investigative agencies of the country and is responsible for a wide variety of criminal and national security matters.

Armed police forces are those police units which deal with serious law and order situations requiring a higher level of armed expertise than normal. Such forces are often involved with combating banditry and Naxalites. They are responsible for emergencies and crowd control issues. These police forces could also be sent to suppress outbreaks of student or labor unrest, organized crime, and communal riots in order to maintain key guard posts and to participate in anti-terrorist operations. Depending on the type of assignment allotted, they are also provided with weapons. Unarmed police personnel are forces which are employed for milder forms of crimes which do not require much expertise. Thus, these forces do not require weapons. 
Since the police personnel play an important role in the criminal justice system and also work as agents of social change and protectors of law, it becomes extremely important for us to know as to how happy and satisfied are they with their jobs and life. The police personnel need to work in complex situations which demand quick decisions and fast actions and thus put them under a lot of stress. Therefore, it is of utmost importance to know and understand what type of job pressures do they face and how they cope and how much satisfied are they with their work.

\section{OBJECTIVES:}

- To measure the Occupational stress Level of Armed and Unarmed police Officers of the Gujarat State.

- To measure the Occupational stress Level of Male and Female police officers of Gujarat State.

- To measure the Job satisfaction Level of the Armed and Unarmed Police officers of Gujarat State.

- To measure the Job satisfaction Level of the Male and female police officers of Gujarat State.

\section{Hypotheses:}

1. There is no significant difference between Occupational Stress of Armed and Unarmed Officers.

2. There is no significant difference between Occupational Stress of male and female Police Officers.

3. There is no significant difference between Job Satisfaction of Armed and Unarmed Officers.

4. There is no significant difference between Job Satisfaction of male and female Police Officers.

\section{METHOD:}

\section{Sample:}

According to the purpose of the present study, 60 Armed Police Officers and 60 Unarmed Police Officers were taken from different parts of Gujarat State. Out of them $50 \%$ were male and $50 \%$ were female Police officers in both groups.

\section{Tools:}

\section{Occupational Stress Index (OSI):}

To measure job stress Occupational Stress Index developed by Srivastava and Singh (1984) was used. The authors have claimed that the tool may be conveniently administered to all categories of employees. The scale consisted of forty six items, each to be rated on five point scale. Out of 46 items, 28 were true keyed and rests 18 were false keyed. The validity of Occupational stress index was determined by computing co-efficient of correlation between scales on the OSI and the various measures of job attitude and job behavior. Split half method was applied to establish the reliability of the scale which was found to be 0.935 by the authors. 


\section{Job Satisfaction Scale (JSS):}

The job satisfaction scale developed by Singh \& Sharma was used to measure job satisfaction among the Armed and Unarmed Police officers. The scale has a very wide acceptance in measuring psychological aspects of functioning in any profession. It consisted of 80 statements in the pilot study. After try out only 30 statements were retained in the final. The test retest reliability of the scale works out to be 0.978 . The scale compares favourably with Muthayya's job satisfaction questionnaire giving a validity coefficient of .743 . The scale measures job satisfaction in two types of areas - job-intrinsic (factors lying in the job itself) and job-extrinsic (factors lying - 106 - 106 outside the job). These areas are covered in 30 statements. Each statement had five alternatives from which a respondent had to choose any one which candidly expressed his response. Q. No. 6, 11, 13, 19, 23 and 25 had job concrete statements whereas jobabstract statements were in the form of Q.No. 8, 15, 16, 17, 21 and 27. Job extrinsic statements found their place in Q.No. 1, 3, 4, 7, 10, 12, 26 and 30. Economic and community growth statements were numbered as 2, 5, 9, 18 and 14, 22, 24, 28 and 29 respectively.

\section{Procedure:}

For data collection, the investigator explained the purpose of the study to the subjects. For this, total 60 Armed Police officers, 60 Unarmed Police officers were taken as a sample form different parts of Gujarat State. Occupational Stress Index and Job Satisfaction inventory were administered. The investigator assured them that their responses would be kept strictly confidential and would be utilized for the research purpose only after which the data was collected individually and was analysed later.

\section{RESULTS AND DISCUSSION:}

The main objective of the present study was to understand the Occupational Stress and Job satisfaction level among armed and Unarmed Police Officers. For this, statistical ' $t$ ' method was used.

Results and discussion of the present study are as under:

Table-1 Occupational Stress of Armed and Unarmed Police Officers

\begin{tabular}{|lccrcrl|}
\hline Group & $\mathbf{N}$ & Mean & SD & SED & 't' & Sign. \\
\hline Armed & 60 & 96.75 & 43.28 & & & \\
Unarmed & 60 & 109.82 & 45.73 & & & \\
& & & & & & \\
\hline
\end{tabular}

Non. Significant at 0.05 level

Table-1 shows occupational Stress of Armed and Unarmed Police officers. For the Armed Police officers mean is 96.75 and for unarmed Police officers mean is 109.82. S.D. for Armed Police officers is 43.28 and for female is 45.73. For both groups ' $t$ ' value is 1.51 and level of significance is not significant. Thus the null hypothesis, number 1, which states "There is no significant difference between Occupational Stress of Armed and Unarmed Officers." was 
accepted. It means that the Occupational Stress level of Armed and Unarmed Police officers was found to be same.

Table-2 Occupational Stress of male and female Police officers

\begin{tabular}{|lcccccc|}
\hline Group & $\mathbf{N}$ & Mean & SD & SED & 't' & Sign. \\
\hline Male & 60 & 107.08 & 45.96 & & & \\
Female & 60 & 99.48 & 43.70 & & & \\
\end{tabular}

Non. Significant at 0.05 level

Table-2 shows occupational Stress of Male and Female Police officers of both groups. For the Male Police officers mean is 107.08 and for Female Police officers mean is 99.48. S.D. for Male Police officers is 45.96 and for female is 43.70 . For both groups ' $t$ ' value is 0.88 and level of significance is not significant. Thus the null hypothesis, number 2, which states "There is no significant difference between Occupational Stress of male and female Police Officers." was accepted. It means that the Occupational Stress level of Male and Female Police officers was found to be same.

Table-3 Job Satisfaction of Armed and Unarmed Police Officers

\begin{tabular}{|lrcrcrc|}
\hline Group & $\mathbf{N}$ & Mean & SD & SED & 't' & Sign. \\
\hline Armed & 60 & 21.72 & 0.69 & & & \\
& & & & 0.969 & 0.1032 & NS \\
Unarmed & 60 & 21.62 & 0.68 & & & \\
\hline
\end{tabular}

Non- significant at 0.05 levels

Table-3 shows Job Satisfaction of Armed and Unarmed Police officers. For the Armed Police officers mean is 21.72 and for Unarmed Police officers mean is 21.62. S.D. for Armed Police officers is 0.69 and for female is 0.68 . For both groups ' $t$ ' value is 0.1032 and level of significance is not significant. Thus the null hypothesis, number 3, which states "There is no significant difference between Job Satisfaction of Armed and Unarmed Officers." was accepted. It means that the Job Satisfaction level of Armed and Unarmed Police officers was found to be same.

Table-4 Job Satisfaction of Male and female Police officers

\begin{tabular}{|lcccccc|}
\hline Group & $\mathbf{N}$ & Mean & SD & SED & 't' & Sign. \\
\hline Male & 60 & 19.77 & 5.91 & & & \\
& & & & 0.890 & 4.27 & 0.01 \\
Female & 60 & 23.57 & 3.74 & & & \\
\hline
\end{tabular}

Significant at 0.01 level 
Table-4 shows Job Satisfaction of Male and Female Police officers of both the groups. For the Male Police officers mean is 19.77 and for Female Police officers mean is 23.57. S.D. for Male Police officers is 5.91 and for females is 3.74. For both groups ' $t$ ' value is 4.27 and level of significance is 0.01 . Thus the null hypothesis, number 3 , which states "There is no significant difference between Job Satisfaction of male and female Police Officers." was rejected. It means that the Job Satisfaction level of Female Police officers was higher than that of Male Police officers.

\section{CONCLUSION:}

1. There is no significant difference between Occupational Stress of Armed and Unarmed Police officers and similarly there is no Significant Difference between Occupational stress of male and female officers.

2. There is no significant difference between Job Satisfaction Level of Armed and Unarmed Police officers

3. There is a significant difference between Job Satisfaction level of Male and female Police officers which mean Female police officers have more Job Satisfaction level than male Officers.

\section{REFERENCES:}

Ankony, R.C., (1997). The impact of alienation on police officers' sense of mastery and their subsequent willingness to participate in proactive enforcement. Dissertations Abstracts International, 58(3). (UMI No. 9725811).

Bhasker,S. (1990, spring). Measuring job stress of the Indian police: An empirical approach. Abhigyan, 30-44.

Brown. J. M., Cooper, C, \& Kiriccaldy, B. (1996). Occupational stress among senior police officers. British Journal of Psychology, 87(1), 31-41.

Bruce Kirkcaldy, Jennifer Brown, Cary L. Cooper (1998), The demographics of occupational stress among police superintendents, Journal of Managerial Psychology, Vol. 13, No.1/2, pp 90-101.

Cooper, C. L., Marshall, J. (1976), Occupational sources of stress: a review of the literature relating to coronary heart disease and mental ill health, Journal of occupational psychology, 49(1): 11-28

Fernando Jaramillo, Robert Nixon, Doreen Sams (2005), The effect of law enforcement stress on organizational commitment, Policing: an International Journal of Police Strategies \& Management, Vol. 28, No.2, pp. 321-336.

George T. Patterson (2002), Predicting the effects of military service experience on stressful occupational events in police officers, Policing: an International Journal of Police Strategies \& Management, Vol. 25, No.3, pp. 602-618.

Hanewicz, W.B. (1978). Police personality: A Jungian perspective. Crime and Delinquency, April 1978, 152-172. 
Hasan Buker, Filip Wiecko (2007), Are causes of police stress global? Policing: an International Journal of Police Strategies \& Management, Vol. 30, No. 2, pp. 291-309.

J. E. Agolla (2009), Occupational Stress among Police Officers: The Case of Botswana Police Service, Research Journal of Business Management 2 (1): 25-35.

Mathur, Pragya (1993). Stress in Police Personnel: A preliminary Survey. NPA Magazine, 45 (2), July-Dec.

Pareek, Udai (1981): Role stress Scale. ORS Scale Booklet, answer sheet and manual. Ahmedabad: Navin Publications

Tripathi, R.C., Naidu, R.K.M. Thapa, K. and Biswas, S.N. (1993). Stress, Health and Performance: A study of Police Organization in Uttar Pradesh. Report submitted to Bureau of police Research \& development February, 1993. 